\title{
Financial Inclusion \& Human Development: A Cross Country Analysis
}

\author{
Ayushi Raichoudhury \\ KIIT School of Management, KIIT University
}

\begin{abstract}
Financial Inclusion has been the area of concern in the recent years. Despite being a policy priority in many countries still 2.5 billion people in the world-do not have access to savings accounts and other formal financial services according to Consultative Group to Assist the Poor (CGAP 2011).The paper attempts to measure financial inclusion using a cross country data set from Financial Access Survey (FAS) and the index of financial inclusion (IFI) developed by Sarma (2012). Then it presents an empirical analysis of the relationship between financial inclusion and human development across countries. It is found that levels of human development and financial inclusion in a country move closely with each other, although a few exceptions exist. The correlation coefficient between IFI and HDI values and ranks was calculated to be 0.82 and 0.85 respectively implying significant positive correlation between the two indices. It is also seen that income level and financial inclusion in a country move closely with each other. Majority of the high income countries are the high IFI countries.
\end{abstract}

Keywords: Financial Inclusion, income level, Index of financial inclusion

\section{Introduction}

Financial inclusion is the access to basic financial services by all groups of people. Financial inclusion has several advantages. First, it facilitates efficient allocation of resources. Second, it reduces cost of capital and improves the day-to-day management of finances. Third, it reduces the growth of informal sources of credit (such as money lenders). Finally, it facilitates a whole range of efficient financial services. The relationship between financial inclusion and development is also well understood in literature (for example see King and Levine, 1993; Beck et al., 2000; Demirgüç-Kunt and Maksimovic, 1998; Beck et al., 2007; Levine, 2005; Klapper et al., 2006; Demirgüç-Kunt et al., 2008).

The importance of financial inclusion is widely recognized and it has become a global agenda now. The Community Reinvestment Act (1997) in United States, The law on exclusion (1998) in France, The Financial Inclusion Task Force in United Kingdom, 
Mzansi (2004) in South Africa, The 'no-frills' accounts and "General Credit Card" schemes of Reserve Bank of India highlights the importance of financial inclusion. However despite all the efforts most poor people in the world lack access to basic financial services. According to Kofi Annan (2003), we need to build inclusive financial system to address the constraints that exclude people from the financial sector.

In this paper, we have used the index financial inclusion (IFI) developed by Sarma (2012) to measure financial inclusion across countries. Then we have compared it with the human development index and analyzed the relationship between financial inclusion and human development.

This paper is organised as follows. The next section discusses financial inclusion and provides a literature review. Section 3 provides the methodology for construction of our financial inclusion index. Section 4 presents the broad relationship between index of financial inclusion (IFI) and Human development index (HDI). Section 5 concludes the paper.

\section{Section 2}

\section{Review of Literature}

Literature on financial inclusion has defined it in a broader concept of social inclusion. Rangarajan Committee on Financial Inclusion (2008) defined it as the process of ensuring access to financial services and timely and adequate credit by the weaker sections and low income groups at an affordable cost. According to Chakraborty (2010) financial inclusion is a strategy for economic development because of the increasing concern that the benefits of economic growth have not been equitably shared. Sarma (2012) defines financial inclusion as a process that ensures the ease of access, availability and usage of the formal financial system for all members of an economy. Sinclair (2001) defined financial exclusion as the inability to access basic financial services in suitable form. According to Conroy (2005) financial exclusion prevents poor people to have access to the formal financial systems of their countries. The definitions make it clear that people at the margins of the society are financially excluded.

Strong relationship between financial development and human capital has been shown in literature (For example see Evans, Green, \&Murinde, 2002). According to King and Levine (1993 a \& b) and Gregorio and Guidotti (1995) higher levels of financial development are positively associated with faster rates of economic growth. The Role of human capital in economic development has also been firmly established by Benhabib and Spiegal (1992). According to Beck, et al., (2007) financial inclusion reduces income inequality and alleviates poverty. Naturally, the lower the level of poverty, the higher is the level of human development. Thus, financial development leads to human development.Chou and Chinn (2001) presented that human capital is a key factor for financial development which in turn leads to further creation of human capital. 
However, literature on how to measure the extent of financial inclusion is limited.Few studieshave measured financial inclusion by the proportion of households having access to financial services i.e. having a bank account. However, such type of data is difficult to obtain as they depend on country wide surveys. Claessens (2006) pointed out that data on the use of financial services by households and firms is limited.Honohan (2008) estimated the number of households having access to banking services for many countries based on survey information through an econometric approach. Several other indicators have been used in Conrad, et al (2008) to assess the extent of financial inclusion such as the number of bank accounts (per 1000 adult population), the number of ATMs (per million people), the number of bank branches (per million people) etc. However, these indicators individually fail to adequately capture the overall extent of financial inclusion. Therefore, we have used a comprehensive measure i.e. Index of financial inclusion (IFI) developed by Sarma (2012) to measure the extent of financial inclusion across countries.

\section{Section 3}

\section{Methodology}

We have followed a multidimensional approach for construction of the index of financial inclusion (IFI). Although it is similar to the UNDP approach for computation of Human Development Index (HDI) and Gender-related Development Index (GDI) it differs in the manner in which dimension indexes are constructed. Instead of using an average of the dimension indexes as in UNDP's methodology, our index is similar to that of Sarma (2012) i.e distance from the worst and ideal situation. In this paper IFI is designed by calculating a dimension index for each dimension of financial inclusion. The dimension index $\mathrm{d}_{\mathrm{i}}$ is calculated by the following formula:

$\mathrm{d}_{\mathrm{i}}=\mathrm{w}_{\mathrm{i}} *\left(\left(\mathrm{~A}_{\mathrm{i}}-\mathrm{m}_{\mathrm{i}}\right) /\left(\mathrm{M}_{\mathrm{i}}-\mathrm{m}_{\mathrm{i}}\right)\right)$

where

$\mathrm{w}_{\mathrm{i}}=$ weight attached to the dimension $\mathrm{i}, 0 \leq \mathrm{w}_{\mathrm{i}} \leq 1$

$\mathrm{A}_{\mathrm{i}}=$ actual value of dimension $\mathrm{i}$

$\mathrm{M}_{\mathrm{i}}=$ upper limit of the value of dimension $\mathrm{i}$, fixed by pre-specified rule

$\mathrm{m}_{\mathrm{i}}=$ lower limit of the value of dimension $\mathrm{i}$, fixed by pre-specified rule

The upper and lower limits used in this paper are discussed in section 3.1

The above formula ensures that $0 \leq \mathrm{d}_{\mathrm{i}} \leq 1$. The country's achievement in dimension $\mathrm{i}$ will be higher if the value of $d_{i}$ is higher. If $n$ dimensions of financial inclusion are considered, then a country's achievement in these dimensions will be given by a point $\mathrm{X}=\left(\mathrm{d}_{1}, \mathrm{~d}_{2}, \mathrm{~d}_{3}, \ldots, \mathrm{d}_{\mathrm{x}}\right)$ on the $\mathrm{n}$-dimensional space. In the $\mathrm{n}$-dimensional space, the point $\mathrm{O}=(0,0,0, \ldots, 0)$ represents the point of worst situation while the point $\mathrm{W}=$ $\left(\mathrm{w}_{1}, \mathrm{w}_{2}, \ldots, \mathrm{w}_{\mathrm{n}}\right)$ represents an ideal situation indicating the highest achievement in all dimensions.

Larger distance between $\mathrm{X}$ and $\mathrm{O}$ indicates higher financial inclusion. And smaller distance between $\mathrm{X}$ and $\mathrm{W}$ also indicates higher financial inclusion. In this paper, we use a simple average of the Euclidian distance between $\mathrm{X}$ and $\mathrm{O}$ and the inverse Euclidian distance between $\mathrm{X}$ and $\mathrm{W}$. Both the distances are normalized by the distance between $\mathrm{O}$ and $\mathrm{W}$, to make them lie between 0 and 1 . The inverse distance between $\mathrm{D}$ and $\mathrm{W}$ is considered for computing the simple average between the 
distances. This makes IFI a number that lies between 0 and 1 and is monotonically increasing. Thus for computation of IFI, first we calculate $\mathrm{X}_{1}$ (distance between $\mathrm{X}$ and $\mathrm{O}$ ) and $\mathrm{X}_{2}$ (inverse distance between $\mathrm{X}$ and $\mathrm{W}$ ) and then take a simple average of $\mathrm{X}_{1}$ and $\mathrm{X}_{2}$ to compute IFI. The formulae are given below:

$$
\begin{aligned}
& \mathrm{X}_{1}=\operatorname{Sqrt}\left(\left(\left(\mathrm{d}_{1}\right)^{\wedge} 2+\left(\mathrm{d}_{2}\right)^{\wedge} 2+. .+\left(\mathrm{d}_{\mathrm{n}}\right)^{\wedge} 2\right) /\left(\left(\mathrm{w}_{1}\right)^{\wedge} 2+\left(\mathrm{w}_{2}\right)^{\wedge} 2+. .+\left(\mathrm{w}_{\mathrm{n}}\right)^{\wedge} 2\right)\right) \\
& \mathrm{X}_{2}=1-\left(\mathrm{Sqrt}_{(}\left(\left(\mathrm{w}_{1}-\mathrm{d}_{1}\right)^{\wedge} 2+\left(\mathrm{w}_{2}-\mathrm{d}_{2}\right)^{\wedge} 2+. .+\left(\left(\mathrm{w}_{3}-\mathrm{d}_{\mathrm{n}}\right)^{\wedge} 2\right) /\left(\left(\mathrm{w}_{1}\right)^{\wedge} 2+\left(\mathrm{w}_{2}\right)^{\wedge} 2+. .+\left(\mathrm{w}_{\mathrm{n}}\right)^{\wedge} 2\right)\right)\right) \\
& \mathrm{IFI}=1 / 2\left(\mathrm{X}_{1}+\mathrm{X}_{2}\right)
\end{aligned}
$$

$\mathrm{X}_{1}$ gives the normalized Euclidean distance of $\mathrm{X}$ from the worst point $\mathrm{O}$, normalized by the distance between the worst point $\mathrm{O}$ and the ideal point $\mathrm{W}$. This is done to make the value of $X_{1}$ lie between 0 and 1 . Higher value of $X_{1}$ implies more financial inclusion.

$\mathrm{X}_{2}$ gives the inverse normalizedEuclidean distance of $\mathrm{X}$ from the ideal point $\mathrm{W}$. The numerator gives the Euclidean distance of $\mathrm{X}$ from the ideal point $\mathrm{W}$, normalizing it by the denominator and subtracting by 1 gives the inverse normalized distance. This is done to make the value of $X_{2}$ lie between 0 and 1 . The higher distance is considered because higher value of $\mathrm{X}_{2}$ implies higher financial inclusion.

IFI is the simple average of $X_{1}$ and $X_{2}$ indicating the distance from both the worst point and the ideal point. Since, we consider all dimensions to be equally important in measuring the inclusiveness of a financial system, then $\mathrm{w}_{\mathrm{i}}=1$ for all $\mathrm{i}$. Thus, the ideal situation will be $\mathrm{W}=(1,1,1, \ldots, 1)$ in the $n$-dimensional space. The formula will be:

$$
\begin{aligned}
& \mathrm{A}_{1}=\operatorname{Sqrt}\left(\left(\mathrm{d}_{1}\right)^{\wedge} 2+\left(\mathrm{d}_{2}\right)^{\wedge} 2+. .+\left(\mathrm{d}_{\mathrm{n}}\right)^{\wedge} 2\right) / \mathrm{n} \\
& \mathrm{A}_{2}=1-\operatorname{Sqrt}\left(\left(\left(1-\mathrm{d}_{1}\right)^{\wedge} 2+\left(1-\mathrm{d}_{2}\right)^{\wedge} 2+. .+\left(1-\mathrm{d}_{\mathrm{n}}\right)^{\wedge} 2\right) / \mathrm{n}\right) \\
& \mathrm{IFI}=1 / 2\left(\mathrm{~A}_{1}+\mathrm{A}_{2}\right)
\end{aligned}
$$

In this study, we have identified three dimensions for evaluating the extent of financial inclusion: banking penetration to measure depth, availability of banking services and usage of banking services.

\section{Dimension 1 - Banking penetration}

It indicates that an inclusive financial system should have as many users as possible. The proportion of people having a bank account is a measure of the banking penetration of the system. However, data on the proportion of people having a bank account is not readily available. Therefore, we use number of deposit bank accounts per 1000 adult population as an indicator for this dimension.

\section{Dimension 2 - Availability of banking services}

The availability of banking services can be indicated by the number of bank branches per 1000 population, number of ATM per 1000 population, number of bank employees per customer. However, due to lack of consistent data on number of ATM per 1000 population and number of bank employees per customer, we use number of bank branches per 1000 population to measure this dimension.

\section{Dimension 3 - Usage}


The usage of banking services is adequately important. Merely having a bank account is not enough. Usage can be in the forms of credit, deposit, payments, remittances, transfer etc. However, cross country comparable data on payments, remittances and transfers are not available till date. Hence, we use the data on volume of credit to the private sector and deposit mobilized from the private sector as proportion of the country's GDP to measure this dimension.

\section{Section 3.1}

\section{Upper and lower limits for dimensions}

To normalize the dimension indexes and have values between 0 and $\mathrm{w}_{\mathrm{i}}$, we have fixed the value of upper limit $\left(\mathrm{M}_{\mathrm{i}}\right)$ and lower limit $\left(\mathrm{m}_{\mathrm{i}}\right)$ for each dimension as followed by Sarma (2012). While 0 can be safely the lower bound for all dimensions, it is difficult to fix the upper bound of a dimension. Theoretically, it is not possible to arrive at a 'maximum' or even an 'optimum' level of achievement for a dimension of financial inclusion. Selecting the empirically observed highest value of a dimension as the upper limit is a straightforward methodology. But if this happens to be 'an outlier', then it will distort the scale of the index. Secondly, the empirically observed highest value as the upper bound may be different for different years. Thus, comparing such an index across time will be difficult.

Therefore, we consider the following upper bounds to be reasonable for different dimensions:

$\mathrm{M}_{\mathrm{p}}=$ upper limit for computing dimension index for penetration dimension $=2500$ (indicating on an average of at least 2 deposit accounts per adult).

$\mathrm{M}_{\mathrm{a} 1}=$ upper limit for computing $1^{\text {st }}$ index of availability dimension $=60$ (indicating about 1667 clients per bank branch).

$\mathrm{M}_{\mathrm{a} 2}=$ upper limit for computing $2^{\text {nd }}$ index of availability dimension $=120$ (indicating 1 ATM per 833 adults).

$\mathrm{M}_{\mathrm{p}}=$ upper limit for computing dimension index for usage dimension $=300$ (indicating a credit+deposit to GDP ratio of 3 )

If a country has a dimension value greater than the upper bounds, then it is set equal to the upper bound. By setting the upper limits, we avoid comparing countries against excessively high benchmarks.

\section{Section 3.2}

\section{Weights assigned to the dimensions}

All the three dimensions considered here are equally important for an inclusive financial system. We assign a weight 1 to the penetration dimensionas banking penetration is the primary indicator of financial inclusion. We assign a weight 0.5 for the index of availability dimension because data only on physical outlets can give an incomplete picture of the availability of banking services. Countries have moved towards internet and mobile banking. Similarly, we assign a weight 0.5 for the index 
of usage as other services of the banking system, such as payments, transfers and remittances are not included.

Given these weights, a country $\mathrm{K}$ is represented by a point (pk, ak, uk ) in the three dimensional space, such that $0<=\mathrm{pk}<=1,0<=\mathrm{ak}<=0.5,0<=\mathrm{uk}<=0.5$, where pk, ak and uk are the dimension indexes for country $\mathrm{k}$. The point $(0,0,0)$ will indicate complete financial exclusion (worst situation) and the point $(1,0.5,0.5)$ will indicate complete financial inclusion (best situation). The IFI for the country $\mathrm{k}$ is measured by the simple average of normalized Euclidean distance of the point (pk, ak, uk ) from the point $(0,0,0)$ and its normalized inverse Euclidian distance the ideal point $(1,0.5$, $0.5) .$. The final formula with weights will be:

$\mathrm{X}_{1}=\operatorname{Sqrt}\left(\left(\left(\mathrm{p}_{\mathrm{k}}\right)^{\wedge} 2+\left(\mathrm{a}_{\mathrm{k}}\right)^{\wedge} 2+\left(\mathrm{u}_{\mathrm{k}}\right)^{\wedge} 2\right) /\left((1.5)^{\wedge} 2\right)\right)$

$\mathrm{X}_{2}=1-\left(\operatorname{Sqrt}\left(\left(\left(1-\mathrm{p}_{\mathrm{k}}\right)^{\wedge} 2+\left(0.5-\mathrm{a}_{\mathrm{k}}\right)^{\wedge} 2+\left(0.5-\mathrm{u}_{\mathrm{k}}\right)^{\wedge} 2\right) /\left((1.5)^{\wedge} 2\right)\right)\right.$

$\mathrm{IFI}=1 / 2\left(\mathrm{X}_{1}+\mathrm{X}_{2}\right)$

\section{Section 3.3}

\section{Computation of IFI for Countries around the World for 2013}

First we describe the data used for the calculation of IFI and then present the IFI values for as many countries as possible for the year 2013 .

\section{Data}

Data on deposit accounts per 1000 adults is used as a measure of banking penetration, data on number of bank branches is used as an indicator of availability of banking services and total deposit and credit from scheduled commercial banks as a percentage of the Gross Domestic Product (GDP) of a country is used as an indicator of the usage of banking services.

The data used here is extracted from the Financial Access Survey (FAS) database of the International Monetary Fund (IMF). The FAS database provides geographic and demographic indicators of access to finance for 160 countries. The first data set was released by FAS in 2010 .

\section{Section 3.4}

\section{Results}

Table 1 presents the IFI value and rank for various countries for the year 2013. The number of countries for which IFI is calculated depends on the availability of data on the three dimensions. It is evident from the table that different countries are at different levels of financial inclusion. Out of 111 countries, levels of financial inclusion, as measured by IFI, varied from as low as 0.0011 for South Sudan to as high as 0.8268 for Japan. 
Table 1: IFI value and rank of various countries for the year 2013

\begin{tabular}{|c|c|c|c|c|c|}
\hline Countries & D1 & $\mathrm{D} 2$ & D3 & IFI & $\begin{array}{c}\text { IFI } \\
\text { Rank }\end{array}$ \\
\hline San Marino & 1.0000 & 0.5000 & 0.5000 & 1.095119 & 1 \\
\hline Switzerland & 1.0000 & 0.3986 & 0.5000 & 1.034257 & 2 \\
\hline Portugal & 1.0000 & 0.4829 & 0.3655 & 1.019586 & 3 \\
\hline Malta & 1.0000 & 0.3213 & 0.4503 & 0.980679 & 4 \\
\hline Japan & 1.0000 & 0.2796 & 0.3954 & 0.944106 & 5 \\
\hline Italy & 0.8907 & 0.5000 & 0.2678 & 0.917542 & 6 \\
\hline Greece & 1.0000 & 0.2602 & 0.3037 & 0.904816 & 7 \\
\hline Spain & 0.8102 & 0.5000 & 0.3319 & 0.891417 & 8 \\
\hline Malaysia & 1.0000 & 0.0893 & 0.3959 & 0.854386 & 9 \\
\hline Korea, Rep. & 1.0000 & 0.1485 & 0.2704 & 0.846002 & 10 \\
\hline Mauritius & 0.8784 & 0.1765 & 0.4042 & 0.830997 & 11 \\
\hline Bulgaria & 0.7858 & 0.5000 & 0.2168 & 0.829069 & 12 \\
\hline Turkey & 1.0000 & 0.1637 & 0.1973 & 0.828301 & 13 \\
\hline Chile & 1.0000 & 0.1389 & 0.1918 & 0.81702 & 14 \\
\hline Latvia & 1.0000 & 0.1749 & 0.1422 & 0.813541 & 15 \\
\hline Estonia & 1.0000 & 0.1099 & 0.1950 & 0.807117 & 16 \\
\hline Seychelles & 0.8078 & 0.4259 & 0.1152 & 0.78081 & 17 \\
\hline Angola & 1.0000 & 0.1018 & 0.0926 & 0.771438 & 18 \\
\hline Brunei Darussalam & 0.9280 & 0.1870 & 0.1141 & 0.770633 & 19 \\
\hline Czech Republic & 0.8688 & 0.1986 & 0.1871 & 0.766849 & 20 \\
\hline Ukraine & 1.0000 & 0.0019 & 0.1612 & 0.758364 & 21 \\
\hline Ireland & 0.7742 & 0.1878 & 0.2900 & 0.736402 & 22 \\
\hline Finland & 0.9010 & 0.0975 & 0.1286 & 0.72896 & 23 \\
\hline Macedonia, FYR & 0.8195 & 0.1994 & 0.1576 & 0.726483 & 24 \\
\hline Montenegro & 0.6999 & 0.3528 & 0.1492 & 0.698805 & 25 \\
\hline Netherlands & 0.6721 & 0.1410 & 0.3520 & 0.664776 & 26 \\
\hline Lebanon & 0.5575 & 0.2473 & 0.5000 & 0.658919 & 27 \\
\hline Maldives & 0.7049 & 0.1311 & 0.1647 & 0.628246 & 28 \\
\hline Guatemala & 0.6367 & 0.3148 & 0.0906 & 0.621149 & 29 \\
\hline Mongolia & 0.4819 & 0.5000 & 0.2012 & 0.612599 & 30 \\
\hline Venezuela, RB & 0.6749 & 0.1358 & 0.1738 & 0.611755 & 31 \\
\hline Panama & 0.5312 & 0.2020 & 0.4255 & 0.604231 & 32 \\
\hline Bahamas & 0.5474 & 0.2862 & 0.2589 & 0.599641 & 33 \\
\hline Moldova & 0.6789 & 0.0958 & 0.1590 & 0.596292 & 34 \\
\hline Samoa & 0.6319 & 0.1882 & 0.1403 & 0.588912 & 35 \\
\hline Trinidad and Tobago & 0.6701 & 0.1007 & 0.1200 & 0.580066 & 36 \\
\hline Thailand & 0.5985 & 0.0967 & 0.2635 & 0.570023 & 37 \\
\hline South Africa & 0.6218 & 0.0814 & 0.1780 & 0.556645 & 38 \\
\hline Croatia & 0.4929 & 0.2851 & 0.2134 & 0.544275 & 39 \\
\hline Brazil & 0.4540 & 0.3963 & 0.1342 & 0.534615 & 40 \\
\hline Peru & 0.4090 & 0.5000 & 0.0785 & 0.528244 & 41 \\
\hline Argentina & 0.5584 & 0.1076 & 0.0525 & 0.482582 & 42 \\
\hline
\end{tabular}


Table 1: IFI value and rank of various countries for the year 2013 (Cont'd)

\begin{tabular}{|c|c|c|c|c|c|}
\hline Oman & 0.5124 & 0.1650 & 0.1040 & 0.481861 & 43 \\
\hline Kosovo & 0.4879 & 0.1614 & 0.1196 & 0.466684 & 44 \\
\hline Austria & 0.5177 & 0.1259 & 0.0762 & 0.464789 & 45 \\
\hline India & 0.4718 & 0.0967 & 0.1908 & 0.453895 & 46 \\
\hline Bosnia and Herzegovina & 0.4008 & 0.2557 & 0.1579 & 0.447478 & 47 \\
\hline Mexico & 0.4959 & 0.1233 & 0.0433 & 0.43864 & 48 \\
\hline Ecuador & 0.2615 & 0.5000 & 0.0530 & 0.430511 & 49 \\
\hline Georgia & 0.4242 & 0.2038 & 0.0935 & 0.426252 & 50 \\
\hline Azerbaijan & 0.4910 & 0.0808 & 0.0489 & 0.423484 & 51 \\
\hline Fiji & 0.4434 & 0.0877 & 0.1596 & 0.420124 & 52 \\
\hline Hungary & 0.4404 & 0.1236 & 0.1135 & 0.416051 & 53 \\
\hline Belize & 0.3555 & 0.2123 & 0.2016 & 0.409932 & 54 \\
\hline Armenia & 0.4157 & 0.1746 & 0.0956 & 0.409682 & 55 \\
\hline Morocco & 0.3231 & 0.2001 & 0.2832 & 0.40743 & 56 \\
\hline São Tomé and Principe & 0.3993 & 0.1937 & 0.1054 & 0.407058 & 57 \\
\hline Bhutan & 0.3856 & 0.1325 & 0.1721 & 0.394207 & 58 \\
\hline Saudi Arabia & 0.4160 & 0.0701 & 0.1369 & 0.387107 & 59 \\
\hline Guyana & 0.4326 & 0.0646 & 0.0936 & 0.386169 & 60 \\
\hline Jordan & 0.2713 & 0.1656 & 0.3433 & 0.378378 & 61 \\
\hline United Arab Emirates & 0.3268 & 0.0990 & 0.2824 & 0.374005 & 62 \\
\hline Honduras & 0.3381 & 0.1964 & 0.1395 & 0.37192 & 63 \\
\hline Namibia & 0.3277 & 0.1012 & 0.1439 & 0.330632 & 64 \\
\hline Indonesia & 0.3362 & 0.0819 & 0.1050 & 0.319648 & 65 \\
\hline Kenya & 0.3415 & 0.0411 & 0.1207 & 0.316461 & 66 \\
\hline Botswana & 0.3356 & 0.0729 & 0.0902 & 0.31235 & 67 \\
\hline Tonga & 0.2654 & 0.1737 & 0.0856 & 0.293148 & 68 \\
\hline Dominican Republic & 0.2915 & 0.0926 & 0.0541 & 0.274449 & 69 \\
\hline Bolivia & 0.2592 & 0.0929 & 0.1117 & 0.265258 & 70 \\
\hline Bangladesh & 0.2338 & 0.0632 & 0.1794 & 0.258438 & 71 \\
\hline West Bank and Gaza & 0.2281 & 0.0834 & 0.1547 & 0.252039 & 72 \\
\hline Micronesia, Fed. Sts. & 0.2156 & 0.1212 & 0.1198 & 0.244969 & 73 \\
\hline China & 0.0026 & 0.0604 & 0.4258 & 0.230397 & 74 \\
\hline Nepal & 0.1804 & 0.0664 & 0.2027 & 0.229303 & 75 \\
\hline Philippines & 0.2060 & 0.0669 & 0.1001 & 0.21202 & 76 \\
\hline Egypt, Arab Rep. & 0.1725 & 0.0352 & 0.1501 & 0.194333 & 77 \\
\hline Algeria & 0.1835 & 0.0373 & 0.1078 & 0.188232 & 78 \\
\hline Ghana & 0.1925 & 0.0448 & 0.0672 & 0.184931 & 79 \\
\hline Gabon & 0.1465 & 0.0840 & 0.0352 & 0.154104 & 80 \\
\hline Lesotho & 0.1345 & 0.0254 & 0.0769 & 0.136819 & 81 \\
\hline Pakistan & 0.1145 & 0.0728 & 0.0625 & 0.133216 & 82 \\
\hline Papua New Guinea & 0.0951 & 0.0100 & 0.1404 & 0.129656 & 83 \\
\hline Paraguay & 0.0643 & 0.0806 & 0.1135 & 0.121962 & 84 \\
\hline Nicaragua & 0.0936 & 0.0583 & 0.0879 & 0.121135 & 85 \\
\hline
\end{tabular}


Table 1: IFI value and rank of various countries for the year 2013 (Cont'd)

\begin{tabular}{|l|r|r|r|r|c|}
\hline Haiti & 0.1122 & 0.0176 & 0.0813 & 0.11926 & 86 \\
\hline Rwanda & 0.1213 & 0.0446 & 0.0317 & 0.118938 & 87 \\
\hline Djibouti & 0.0445 & 0.0371 & 0.1638 & 0.118252 & 88 \\
\hline Mozambique & 0.0838 & 0.0271 & 0.1070 & 0.111554 & 89 \\
\hline Malawi & 0.0899 & 0.0221 & 0.0935 & 0.108746 & 90 \\
\hline Liberia & 0.0983 & 0.0271 & 0.0742 & 0.108735 & 91 \\
\hline Cambodia & 0.0562 & 0.0343 & 0.1287 & 0.106392 & 92 \\
\hline Solomon Islands & 0.0908 & 0.0534 & 0.0546 & 0.105437 & 93 \\
\hline Zambia & 0.0972 & 0.0351 & 0.0492 & 0.101824 & 94 \\
\hline Kiribati & 0.0832 & 0.0437 & 0.0470 & 0.093553 & 95 \\
\hline Tanzania & 0.0670 & 0.0158 & 0.0670 & 0.079823 & 96 \\
\hline Equatorial Guinea & 0.0715 & 0.0486 & 0.0135 & 0.077647 & 97 \\
\hline Zimbabwe & 0.0384 & 0.0373 & 0.0699 & 0.069393 & 98 \\
\hline Uganda & 0.0636 & 0.0187 & 0.0328 & 0.065555 & 99 \\
\hline Myanmar & 0.0507 & 0.0158 & 0.0252 & 0.052221 & 100 \\
\hline Yemen, Rep. & 0.0403 & 0.0092 & 0.0335 & 0.045251 & 101 \\
\hline Congo, Rep. & 0.0313 & 0.0242 & 0.0337 & 0.044125 & 102 \\
\hline Afghanistan & 0.0445 & 0.0152 & 0.0121 & 0.043407 & 103 \\
\hline Cameroon & 0.0202 & 0.0109 & 0.0400 & 0.035032 & 104 \\
\hline Burundi & 0.0033 & 0.0206 & 0.0463 & 0.033567 & 105 \\
\hline Comoros & 0.0235 & 0.0105 & 0.0067 & 0.023854 & 106 \\
\hline Madagascar & 0.0152 & 0.0089 & 0.0213 & 0.022408 & 107 \\
\hline Guinea & 0.0144 & 0.0094 & 0.0016 & 0.015291 & 108 \\
\hline Congo, Dem. Rep. & 0.0089 & 0.0000 & 0.0194 & 0.015257 & 109 \\
\hline Central African Republic & 0.0109 & 0.0023 & 0.0003 & 0.009592 & 110 \\
\hline South Sudan & 0.0000 & 0.0059 & 0.0000 & 0.003929 & 111 \\
\hline Source: (uthor sown & & & & \\
\hline
\end{tabular}

Source: Author's own calculation

Note: The IFI values calculated in this table are based on the data from FAS database of $I M F$.

The countries are placed into three categories depending on their IFI values. High IFI countries are categorised as those having IFI values between 0.6 and 1. Medium IFI countries are those having IFI values between 0.3 and 0.6. Low IFI countries have IFI values less than 0.3 .

High IFI countries: Countries that have high IFI values are as follows: San Marino, Switzerland, Portugal, Malta, Japan, Italy, Greece, Spain, Malaysia, Korea Republic, Mauritius, Bulgaria, Turkey, Chile, Latvia, Estonia, Seychelles, Angola, Brunei Darussalam, Czech Republic, Ukraine, Ireland, Finland, Macedonia FYR, Montenegro, Netherlands, Lebanon, Maldives, Guatemala, Mongolia, Venezuela RB, Panama, Bahamas, Moldova, Samoa, Trinidad and Tobago, Thailand and South Africa. As seen from the table, majority of the high IFI countries are high income countries. The exceptions are Angola, Bulgaria, Chile, Latvia, Turkey, Malaysia that are middle income countries. 
Medium IFI countries:Croatia, Brazil, Peru, Argentina, Oman, Kosovo, Austria, India, Bosnia and Herzegovina, Mexico, Ecuador, Georgia, Azerbaijan, Fiji, Hungary, Belize, Armenia, Morocco, São Tomé and Principe, Bhutan, Saudi Arabia, Guyana, Jordan, United Arab Emirates, Honduras, Namibia, Indonesia, Kenya, Botswana, Tonga, Dominican Republic, Bolivia, Bangladesh and West Bank and Gaza. This group has majority of middle income countries. Few countries like India, Kosovo and georgia are lower middle income countries with medium IFI values.

Low IFI countries: Micronesia Fed. Sts, China, Nepal, Philippines, Egypt Arab Rep., Algeria, Ghana, Gabon, Lesotho, Pakistan, Papua New Guinea, Paraguay, Nicaragua, Haiti, Rwanda, Djibouti, Mozambique, Malawi, Liberia, Cambodia, Solomon Islands, Zambia, Kiribati, Tanzania, Equatorial Guinea, Zimbabwe, Uganda, Myanmar, Yemen Republic, Congo Republic, Afghanistan, Cameroon, Burundi, Comoros, Madagascar, Guinea, Congo Dem. Rep, Central African Republic and South Sudan. This lisi is dominated by lower middle income and lower income countries. The only exception is Equatorial Guinea which is a high income country.

\section{Section 4}

\section{Relationship between IFI \& HDI}

A comparison of index of financial inclusion (IFI) with human development index (HDI) for 107 countries has been presented along with their ranks (See Table 2). Human Development Index for the countries has been taken from Human Development Report 2013. Three indices have been considered for the calculation of HDI which are income index, education index and health index.

Table 2: Index of financial inclusion and human development index, 2013

\begin{tabular}{|l|c|c|c|c|}
\hline Countries & IFI & Rank & HDI & Rank \\
\hline Switzerland & 1.0343 & 1 & 0.9174 & 1 \\
\hline Portugal & 1.0196 & 2 & 0.8223 & 17 \\
\hline Malta & 0.9807 & 3 & 0.8289 & 15 \\
\hline Japan & 0.9441 & 4 & 0.8901 & 5 \\
\hline Italy & 0.9175 & 5 & 0.8718 & 8 \\
\hline Greece & 0.9048 & 6 & 0.8527 & 11 \\
\hline Spain & 0.8914 & 7 & 0.8689 & 9 \\
\hline Malaysia & 0.8544 & 8 & 0.7710 & 27 \\
\hline Korea, Rep. & 0.8460 & 9 & 0.8907 & 4 \\
\hline Mauritius & 0.8310 & 10 & 0.7710 & 28 \\
\hline Bulgaria & 0.8291 & 11 & 0.7774 & 26 \\
\hline Turkey & 0.8283 & 12 & 0.7586 & 33 \\
\hline Chile & 0.8170 & 13 & 0.8216 & 18 \\
\hline Latvia & 0.8135 & 14 & 0.8105 & 21 \\
\hline Estonia & 0.8071 & 15 & 0.8399 & 13 \\
\hline Seychelles & 0.7808 & 16 & 0.7564 & 34 \\
\hline Angola & 0.7714 & 17 & 0.5263 & 85 \\
\hline Brunei Darussalam & 0.7706 & 18 & 0.8518 & 12 \\
\hline
\end{tabular}


Table 2: Index of financial inclusion and human development index, 2013(Cont'd)

\begin{tabular}{|c|c|c|c|c|}
\hline Czech Republic & 0.7668 & 19 & 0.8613 & 10 \\
\hline Ukraine & 0.7584 & 20 & 0.7340 & 41 \\
\hline Ireland & 0.7364 & 21 & 0.8993 & 3 \\
\hline Finland & 0.7290 & 22 & 0.8790 & 7 \\
\hline Macedonia, FYR & 0.7265 & 23 & 0.7321 & 42 \\
\hline Montenegro & 0.6988 & 24 & 0.7894 & 23 \\
\hline Netherlands & 0.6648 & 25 & 0.9153 & 2 \\
\hline Lebanon & 0.6589 & 26 & 0.7650 & 31 \\
\hline Maldives & 0.6282 & 27 & 0.6979 & 53 \\
\hline Guatemala & 0.6211 & 28 & 0.6281 & 67 \\
\hline Mongolia & 0.6126 & 29 & 0.6979 & 54 \\
\hline Venezuela, RB & 0.6118 & 30 & 0.7637 & 32 \\
\hline Panama & 0.6042 & 31 & 0.7654 & 30 \\
\hline Bahamas & 0.5996 & 32 & 0.7894 & 24 \\
\hline Moldova & 0.5963 & 33 & 0.6627 & 62 \\
\hline Samoa & 0.5889 & 34 & 0.6937 & 55 \\
\hline Trinidad and Tobago & 0.5801 & 35 & 0.7658 & 29 \\
\hline Thailand & 0.5700 & 36 & 0.7219 & 47 \\
\hline South Africa & 0.5566 & 37 & 0.6578 & 64 \\
\hline Croatia & 0.5443 & 38 & 0.8123 & 20 \\
\hline Brazil & 0.5346 & 39 & 0.7438 & 38 \\
\hline Peru & 0.5282 & 40 & 0.7368 & 40 \\
\hline Argentina & 0.4826 & 41 & 0.8083 & 22 \\
\hline Oman & 0.4819 & 42 & 0.7826 & 25 \\
\hline Austria & 0.4648 & 43 & 0.8812 & 6 \\
\hline India & 0.4539 & 44 & 0.5857 & 73 \\
\hline Bosnia and Herzegovina & 0.4475 & 45 & 0.7308 & 44 \\
\hline Mexico & 0.4386 & 46 & 0.7558 & 35 \\
\hline Ecuador & 0.4305 & 47 & 0.7106 & 50 \\
\hline Georgia & 0.4263 & 48 & 0.7438 & 39 \\
\hline Azerbaijan & 0.4235 & 49 & 0.7474 & 36 \\
\hline Fiji & 0.4201 & 50 & 0.7241 & 46 \\
\hline Hungary & 0.4161 & 51 & 0.8181 & 19 \\
\hline Belize & 0.4099 & 52 & 0.7316 & 43 \\
\hline Armenia & 0.4097 & 53 & 0.7301 & 45 \\
\hline Morocco & 0.4074 & 54 & 0.6167 & 70 \\
\hline São Tomé and Principe & 0.4071 & 55 & 0.5579 & 79 \\
\hline Bhutan & 0.3942 & 56 & 0.5841 & 74 \\
\hline Saudi Arabia & 0.3871 & 57 & 0.8355 & 14 \\
\hline Guyana & 0.3862 & 58 & 0.6380 & 65 \\
\hline Jordan & 0.3784 & 59 & 0.7455 & 37 \\
\hline United Arab Emirates & 0.3740 & 60 & 0.8272 & 16 \\
\hline Honduras & 0.3719 & 61 & 0.6172 & 69 \\
\hline
\end{tabular}


Table 2: Index of financial inclusion and human development index, 2013(Cont'd)

\begin{tabular}{|c|c|c|c|c|}
\hline Namibia & 0.3306 & 62 & 0.6241 & 68 \\
\hline Indonesia & 0.3196 & 63 & 0.6843 & 56 \\
\hline Kenya & 0.3165 & 64 & 0.5351 & 84 \\
\hline Botswana & 0.3123 & 65 & 0.6833 & 57 \\
\hline Tonga & 0.2931 & 66 & 0.7050 & 51 \\
\hline Dominican Republic & 0.2744 & 67 & 0.7002 & 52 \\
\hline Bolivia & 0.2653 & 68 & 0.6673 & 61 \\
\hline Bangladesh & 0.2584 & 69 & 0.5579 & 80 \\
\hline Micronesia, Fed. Sts. & 0.2450 & 70 & 0.6304 & 66 \\
\hline China & 0.2304 & 71 & 0.7191 & 48 \\
\hline Nepal & 0.2293 & 72 & 0.5396 & 82 \\
\hline Philippines & 0.2120 & 73 & 0.6595 & 63 \\
\hline Egypt, Arab Rep. & 0.1943 & 74 & 0.6816 & 58 \\
\hline Algeria & 0.1882 & 75 & 0.7166 & 49 \\
\hline Ghana & 0.1849 & 76 & 0.5732 & 76 \\
\hline Gabon & 0.1541 & 77 & 0.6737 & 60 \\
\hline Lesotho & 0.1368 & 78 & 0.4862 & 96 \\
\hline Pakistan & 0.1332 & 79 & 0.5365 & 83 \\
\hline Papua New Guinea & 0.1297 & 80 & 0.4915 & 92 \\
\hline Paraguay & 0.1220 & 81 & 0.6759 & 59 \\
\hline Nicaragua & 0.1211 & 82 & 0.6140 & 71 \\
\hline Haiti & 0.1193 & 83 & 0.4714 & 98 \\
\hline Rwanda & 0.1189 & 84 & 0.5057 & 87 \\
\hline Djibouti & 0.1183 & 85 & 0.4674 & 100 \\
\hline Mozambique & 0.1116 & 86 & 0.3926 & 103 \\
\hline Malawi & 0.1087 & 87 & 0.4140 & 101 \\
\hline Liberia & 0.1087 & 88 & 0.4118 & 102 \\
\hline Cambodia & 0.1064 & 89 & 0.5840 & 75 \\
\hline Solomon Islands & 0.1054 & 90 & 0.4906 & 93 \\
\hline Zambia & 0.1018 & 91 & 0.5607 & 78 \\
\hline Kiribati & 0.0936 & 92 & 0.6074 & 72 \\
\hline Tanzania & 0.0798 & 93 & 0.4884 & 94 \\
\hline Equatorial Guinea & 0.0776 & 94 & 0.5560 & 81 \\
\hline Zimbabwe & 0.0694 & 95 & 0.4920 & 91 \\
\hline Uganda & 0.0656 & 96 & 0.4835 & 97 \\
\hline Myanmar & 0.0522 & 97 & 0.5235 & 86 \\
\hline Yemen, Rep. & 0.0453 & 98 & 0.4999 & 89 \\
\hline Congo, Rep. & 0.0441 & 99 & 0.5641 & 77 \\
\hline Afghanistan & 0.0434 & 100 & 0.4679 & 99 \\
\hline Cameroon & 0.0350 & 101 & 0.5044 & 88 \\
\hline Burundi & 0.0336 & 102 & 0.3894 & 105 \\
\hline Comoros & 0.0239 & 103 & 0.4877 & 95 \\
\hline Madagascar & 0.0224 & 104 & 0.4979 & 90 \\
\hline
\end{tabular}


Table 2: Index of financial inclusion and human development index, 2013(Cont'd)

\begin{tabular}{|l|l|l|l|l|}
\hline Guinea & 0.0153 & 105 & 0.3919 & 104 \\
\hline Congo, Dem. Rep. & 0.0153 & 106 & 0.3379 & 107 \\
\hline Central African Republic & 0.0096 & 107 & 0.3405 & 106 \\
\hline
\end{tabular}

Source: Author's own calculation

Table 2 reveals that IFI and HDI for the countries seem to move in the same direction and closely with each other, although few exceptions exist. It is statistically proved by the fact that the correlation coefficient between IFI and HDI values and ranks was calculated to be 0.82 and 0.85 respectively implying significant positive correlation between the two indices. This result shows that the states with relatively high level of financial inclusion are also the states with high level of human development and vice versa.

The countries like Switzerland, Japan, Italy, Spain and South Korea which rank high in financial inclusion are also found to have high human development index. Furthermore, the countries like Congo Democratic Republic, Central African Republic, Guinea, Burundi, and Afghanistan which rank lowest on index of financial inclusion perform poorly on human development index as well.

Besides, countries such Austria, Netherlands and Ireland have relatively higher levels of human development as compared to their levels of financial inclusion.Similarily, countries like Portugal, Malta, Malaysia and Turkey perform relatively better in financial inclusion than in human development.

\section{Section 5}

\section{Conclusion}

This paper throws some light on the extent of financial inclusion across different countries on the basis of an index of financial inclusion. A comparative analysis is also conducted in the paper to examine the association between the process of financial inclusion and the level of human development. The analysis indicates that the level of human developmentand that of financial inclusion are positively correlated. Thus the countries with a relatively high level of financial inclusion are also the countries having a high level of human development. The countries like Switzerland, Japan, Italy, Spain and South Korea which rank high in financial inclusion are also found to have high human development index. Furthermore, the countries like Congo Democratic Republic, Central African Republic, Guinea, Burundi, and Afghanistan which rank lowest on index of financial inclusion perform poorly on human development index as well.

From this study, we realize that there is a strong positive relationship between financial inclusion and human development. Therefore the countries should incorporate financial inclusion in the bigger objective of economic and social development. There is a need for coordinated effort towards encouraging financial inclusion. New technological advances in banking sector such as mobile banking and internet banking could not be included in our empirical analyses due to unavailability 
of relevant data. Similarly, information on various parameters such as affordability, timeliness and quality of banking services is also not obtainable.

\section{References}

Mandira Sarma. (2012). Index of Financial Inclusion - A measure of financial sector inclusiveness. Berlin: Berlin Working Papers on Money, Finance, Trade and Development

CGAP. (2011). Global Standard-Setting Bodies and Financial Inclusion for the Poor: Toward Proportionate Standards and Guidance.Washington, D.C.: CGAP

Robert G. King\& Ross Levine. (1993), "Finance and Growth: Schumpeter Might be Right", The Quarterly Journal of Economics, Vol. 108, No. 3,pp. 717-737

AsliDemirgüç-Kunt, Vojislav Maksimovic. (1998), "Law, Finance, and Firm Growth." The Journal of Finance, Vol. 53, No. 6, pp. 2107-2137

Beck, Thorsten., Ross Levine., and Norman Loayza.(2000). "Finance and the Sources of Growth", Journal of Financial Economics 58: 261-300.

Levine, Ross. (2005). Finance and Growth: Theory and Evidence. In Handbook of Economic Growth, ed. Philippe Aghion and Steven N. Durlauf, 865-934. Amsterdam: Elsevier

Beck, T., A. Demirguc-Kunt., M. Soledad., and M. Peria. (2007), "Reaching Out: Access to And Use of Banking Services Across Countries", Journal of Financial Economics, Vol. 85, No. 1, pp. 234-266.

AsliDemirgüç-Kunt., and Ross Levine.(2008). Finance, Financial Sector Policies, and Long-Run Growth.World Bank: Policy Research Working Paper 4469

Rangarajan Committee (2008), Report of the Committee on Financial Inclusion, Government ofIndia.

Sinclair, S. P. (2001), Financial Exclusion: An Introductory Survey. Report of Centre forResearch in Socially Inclusive Services, Heriot-Watt University, Edinburgh.

Conroy, J. (2005). "APEC And Financial Exclusion: Missed Opportunities For CollectiveAction?"Asia-Pacific Development Journal , 12(1).

AlunDwyfor Evans., Christopher J. Green., and Victor Murinde. (2002), "Human capital and financial development in economic growth: new evidence using the translog production function". International Journal of Finance \& Economics, Volume 7, Issue 2, pages 123-140

King, R.G., and R. Levine.(1993a), "Finance and growth: Schumpeter might be right". Quarterly Journal of Economics CVIII, 717-738 
King, R.G., and R. Levine.(1993b). Finance, entrepreneurship, and growth: Theory and evidence. Working paper (World Bank, Washington, DC).

Benhabib, J., and M. Speigel.(1992). Growth accounting with physical and human capital, Working paper (New York University, New York).

Beck, Thorsten.,Asli Demirgüç-Kunt., and Ross Levine. (2007). "Finance, Inequality, and the Poor." Journal of Economic Growth, 12, 27-49.

YK Chou., \& M Chinn.(2001).Human Capital, Financial Innovations and Growth: A Theoretical Approach. Research Paper Series, No 826, Melbourne, Department of Economics, University of Melbourne.

Honohan, P. (2008), "Cross-Country Variation in Household Access to Financial Services." Journal of Banking and Finance 32: 2493-2500 